\title{
Effects of HOTS Techniques through Modular Instructions in Teaching High School Chemistry in MSU- Balindong High School
}

\author{
Anabelie Valdez, Solaiman Mangorsi, Vilma Hambre, Dayamun Magdara, and Maryam Manalundong
}

\begin{abstract}
A combined quantitative-qualitative techniques and analysis was used in this experimental study involving eighty seven (87) third year high school students in MSUBalindong Community High School during 2007-2008 calendar years. They were then distributed into three (3) groups: experimental group, control group and the pilot testing group. The respondent's performance on HOTS questions, learning style, motivation style, creativity and interest were measured at the beginning and at the end of the study. Experimental group exposure on modular instructions using HOTS techniques involving multimodal strategies shows significant effect as compared to the control group. Most of them favored the HOTS techniques and modular instructions and they found it difficult yet more interesting, challenging and enjoyable.
\end{abstract}

Index Terms-Critical thinking, creativity, and motivation, modular instruction, science education.

\section{INTRODUCTION}

Quantitative - qualitative techniques have been used to explore the effects of Higher Order Thinking Skills (HOTS) through modular instructions in teaching high school chemistry. As teacher, teaching is a profession of paramount importance both qualitatively and quantitatively important in serving education. So, we educator is obligated to not simply to bring out but to bring out the best among our students. A major issue faced by the educational system worldwide like in the Philippines case in particular is the low performance of the students in Science and Mathematics. Filipino students ranked 3rd and 4th from the bottom in math and science respectively on the two consecutive study conducted by the Third International Math and Science Survey TIMSS and TIMSS-R [1].

This low and alarming performance evidently indicate that Filipino students are not sufficiently trained to answer HOTS questions. Valdez [2]" research findings revealed that students in MSU-Balindong Community School were poor in HOTS questions in general science because apparently they are used to deal with simple recall questions only.

Result of the System Wide Admission and Scholarship Examination (SASE) given by the Mindanao State

Manuscript received April 20, 2013; revised June 30, 2013.

A. Valdez, S. Mangorsi, D. Magdara, and M. Manalundong are with the Mindanao State University, Marawi City Philippines (email: anabelievillavaldez@gmail.com, sdmangorsi@yahoo.com.ph, dayamunmagdara@yahoo.com, maryammanalu@yahoo.com).

V. Hambre is with the Department of Education, Iligan City Philippines (email: vdhambre@yahoo.com).
University (MSU) showed that some of the high schools department in the university could not make even $1 \%$ of their students pass the said examination. The trend of MSUBalindong performance is a case in point. In the year 20052006, only seven (7) out of 70 graduating students who took the SASE examination were able to pass the said examination. In 2006-2007, only seven (7) out of 60 students who took the same successfully hurdled the test. The results of other examinations taken by graduating students of MSU- Balindong Community High School - i.e. DOST-SEI Scholarship Test - do not provide any consolation. None of the examinees passed the scholarship examination.

To eradicate or just improve the quality education HOTS development among students is a pivotal technique for teaching instructions. HOTS are a creative program designed to enhance students learning style, creativity, interest, motivation and achievement. Research findings internationally, showed that HOTS produce learning gains of low-achieving students in grades 4-7 who demonstrate a great intellectual potential that they want to be successful in school. The right educational approach in the hands of a good teacher, and with the support of a principal can unleash this ability [3]. The evaluation made of the MSUBalindong student's performance serves the purpose of a needs analysis. The result points up the need for some intervention strategy that will lift the abilities of students to levels competitive enough to put them on a par with products of other schools, and enable them to pass qualifying and scholarship examinations. Thus, this study is timely and relevance to explore ways to improve student's skills not only for short term goals but, more importantly, for life long and self-directed publication.

\section{ReSEARCh Methodology}

\section{A. Participant of the Study}

A total of 87 third year high school students in MSUBalindong school year 2007-2008 participated in the study. They were grouped into three based on the matched pairing of their previous grades in chemistry. The matched pair is then randomly assigned to respective groups by drawing lots. A total of 38 students are assigned each group in the experimental and control, while 11 students were assigned in the pilot testing of instruments to established validity and reliability.

\section{B. Research Design and Methods}

This study was a quasi - experimental using quantitative and qualitative research design. Quantitative and qualitative 
data was collected during the whole duration of the second grading period using modules for experimental group and chalk-board approach in the control group. Modules consisting three lessons: chemical language, chemical quantities, and stoichiometry designed by the researcher. Each module consist a variety of teaching methods and activities, both qualitative and quantitative approach which calls for HOTS among learners. Both groups were pretested and post-tested using HOTS questions lifted from the TIMSS - like test items in the chemistry components. Moreover, students learning style, motivation style, creativity and interest were also measured before and after the conduct of the study using adapted standardized instruments from expert. Impressions of students in the experimental group were measured qualitatively through journal writing, and reflections. Self assessment questionnaire was also used to obtained additional information about the modular instructions involving HOTS in the teaching-learning process.

\section{RESUlTS}

Descriptive statistics and t-test was used to investigate the effects of HOTS techniques through modular instructions in teaching high school chemistry.

\section{A. Pre-Test and Pos-Test Performance}

As shown in Fig. 1 and Table I pre-test performance in both groups were almost equal. However, in the post-test experimental group performance improved significantly obtaining a mean gain of 18.6 having $t$-value of 0.009 which is significant at $\alpha=.05$

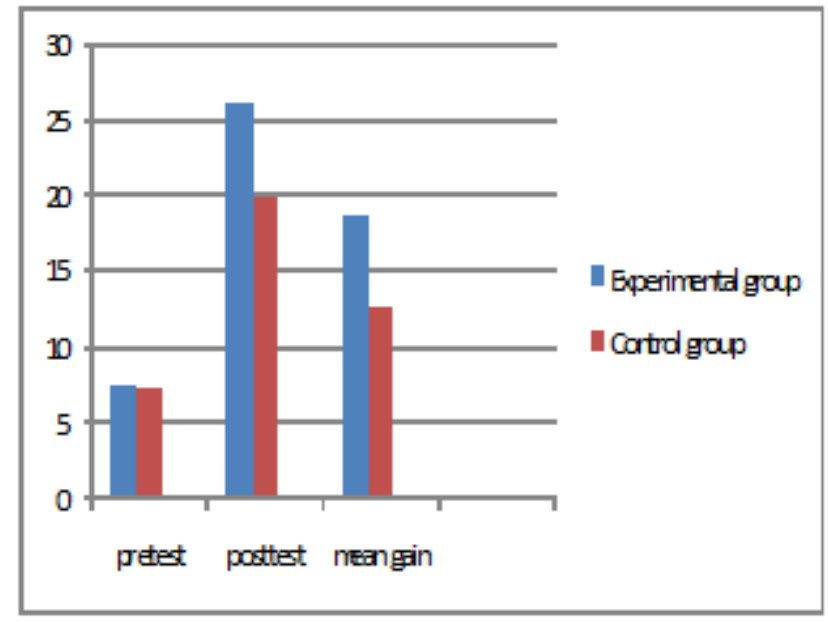

Fig. 1. Pre-test and post-test mean scores of the respondents.

TABLE I: RESPONDENTS PRE-TEST AND POST-TEST

\begin{tabular}{cccccc}
\hline \hline Group & Mean & $\begin{array}{l}\text { Mean } \\
\text { Difference }\end{array}$ & SD & t & decision \\
\hline Exp & 26.14 & & & & $\begin{array}{c}\mathrm{H}_{\mathrm{o}} \\
\text { Contrl }\end{array}$ \\
19.97 & 6.17 & 13.52 & .009 & rejected \\
\hline \hline
\end{tabular}

\section{B. Performance Level of Respondents}

As shown in Table II, performance level of experimental and control group in the HOTS questions during pre-test fells in the poor level $(100 \%)$. However, in the post-test experimental group performance level distributed into poor, below average, average and above average while majority in the control group remained in the poor performance level.

TABLE II: PERFORMANCE LEVEL OF RESPONDNETS

\begin{tabular}{|c|c|c|c|c|c|c|c|}
\hline \multirow{3}{*}{$\begin{array}{l}\text { Score } \\
\text { range }\end{array}$} & \multirow[t]{3}{*}{ Qual. label } & \multicolumn{3}{|c|}{ Experimental group } & \multicolumn{3}{|c|}{ Control group } \\
\hline & & \multirow{2}{*}{$\begin{array}{l}\text { Pre-test } \\
\%\end{array}$} & \multicolumn{2}{|c|}{ Post-test } & \multirow{2}{*}{$\begin{array}{l}\text { Pre-test } \\
\%\end{array}$} & \multicolumn{2}{|c|}{ Post-test } \\
\hline & & & $\boldsymbol{F}$ & $\%$ & & $\boldsymbol{F}$ & $\%$ \\
\hline $56-60$ & Superior & & & & & & \\
\hline $50-55$ & High ave & & & & & & \\
\hline $40-49$ & Above ave. & & 2 & 5.4 & & & \\
\hline 30-39 & Average & & 14 & 37.8 & & 6 & 16.2 \\
\hline $29-25$ & Below ave & & 1 & 2.7 & & 5 & 13.5 \\
\hline 24- & Poor & 100 & 20 & 54 & 100 & 26 & 70.3 \\
\hline \multicolumn{8}{|c|}{ Number of cases: 37} \\
\hline
\end{tabular}

\section{Learning Style}

Students learning style was assessed using "what's' you're learning style which includes visual, auditory, and kinaesthetic [4]. Table 3 present the respondents learning style before and after the study conducted. As shown in Table III, students learning style varies before and after treatment and or teaching. Many respondents in experimental group claimed auditory learning style before treatment, however, after treatment, many of them favored kinaesthetic, followed by visual, and auditory. Learning style in the control group remained the same after teaching the lesson. The shifting of the experimental group learning style was probably influenced by the different activities in the modules. Research conducted internationally showed a negligible correlation between performance and learning style [5]. Buttler [6] believed that learning styles are neutral. All learning style can be successful, but they also could become a stumbling block when overused or applied inappropriately.

TABLE III: LEARNING STYLE OF RESPONDENTS

\begin{tabular}{|c|c|c|c|c|c|c|c|c|}
\hline \multirow[t]{3}{*}{ 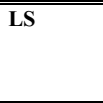 } & \multicolumn{4}{|c|}{ Experimental group } & \multicolumn{4}{|c|}{ Control group } \\
\hline & \multicolumn{2}{|c|}{ Before } & \multicolumn{2}{|c|}{ After } & \multicolumn{2}{|c|}{ Before } & \multicolumn{2}{|r|}{ After } \\
\hline & $\boldsymbol{F}$ & $\%$ & $\boldsymbol{F}$ & $\%$ & $\boldsymbol{F}$ & $\%$ & $\boldsymbol{F}$ & $\%$ \\
\hline $\mathbf{V}$ & 10 & 27 & 11 & 33.3 & 8 & 21 & 9 & $\begin{array}{l}27 . \\
3\end{array}$ \\
\hline $\mathbf{A}$ & 15 & 40.5 & 7 & 21.2 & 11 & $\begin{array}{l}29 \\
7\end{array}$ & 9 & $\begin{array}{l}27 . \\
3\end{array}$ \\
\hline $\mathbf{K}$ & 10 & 27 & 13 & 39.4 & 16 & $\begin{array}{l}42 . \\
1\end{array}$ & 15 & $\begin{array}{l}45 . \\
4\end{array}$ \\
\hline $\mathbf{V} \& \mathbf{K}$ & 2 & 5.4 & 0 & & 1 & 2.6 & & \\
\hline $\mathbf{V} \& A$ & & & 2 & 6.1 & 1 & 2.6 & & \\
\hline Total & 37 & & 33 & & 37 & & 33 & \\
\hline gend: L & $\begin{array}{l}-\mathrm{lec} \\
-\mathrm{Au}\end{array}$ & $\begin{array}{l}\mathrm{ng} \mathrm{s} \\
\text { ry }\end{array}$ & & & $\begin{array}{l}\mathrm{V}- \\
\mathrm{K}-\end{array}$ & $\begin{array}{l}\text { ual } \\
\text { naes }\end{array}$ & & \\
\hline
\end{tabular}

\section{Motivation Style}

Student's motivation style was measured using the Comer motivation style questionnaire which includes goal, social, and learning oriented [7]. Table IV shows that experimental group motivation style remained the same before and after treatment. However, response on socially oriented motivation style increases, the same as true with the learning oriented. In the case of control group, they were socially and learning oriented before teaching while after teaching $50 \%$ becomes socially oriented. Sustaining motivation to learn is strongly dependent on the learner confidence in his or her potential for learning and motivation style [8]. Caster [9] research reports show no 
significant relationship between motivation and motivation style.

TABLE IV: RESPONDENTS MOTIVATION STYLE

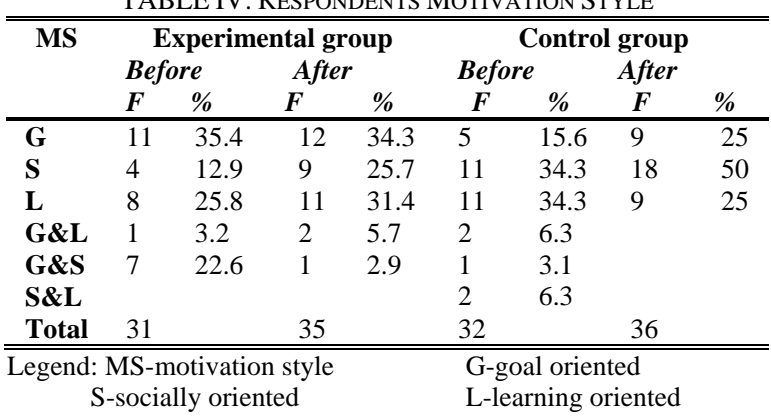

\section{E. Creativity and Interest}

Student's creativity and interest was measured using the Schafer creativity attitude survey [10]. As shown in Table V, control group creativity and interest before teaching was above average, average, and low average. However, after teaching the lessons their creativity and interest become poor, no more above average and only few remained average. These dramatic changes may be affected to the difficulty level of topics. Their creativity and interest were not reawakening due to fact that they were not exposed to any activities. In the case of experimental group, many of them have average creativity and interest and few above average. After treatment, the percentage of low average and above average increases. However, the above average creativity decreases but with the corresponding response of $8.6 \%$ superior in their creativity and interest. Creativity and interest is a vitally important aspect of daily life. It will benefit both extrinsic and intrinsic. Creativity is a dimension of the person and may not be dependent on the intelligent aspect of a person [11].

TABLE V: CREATIVITY AND INTEREST OF RESPONDENTS

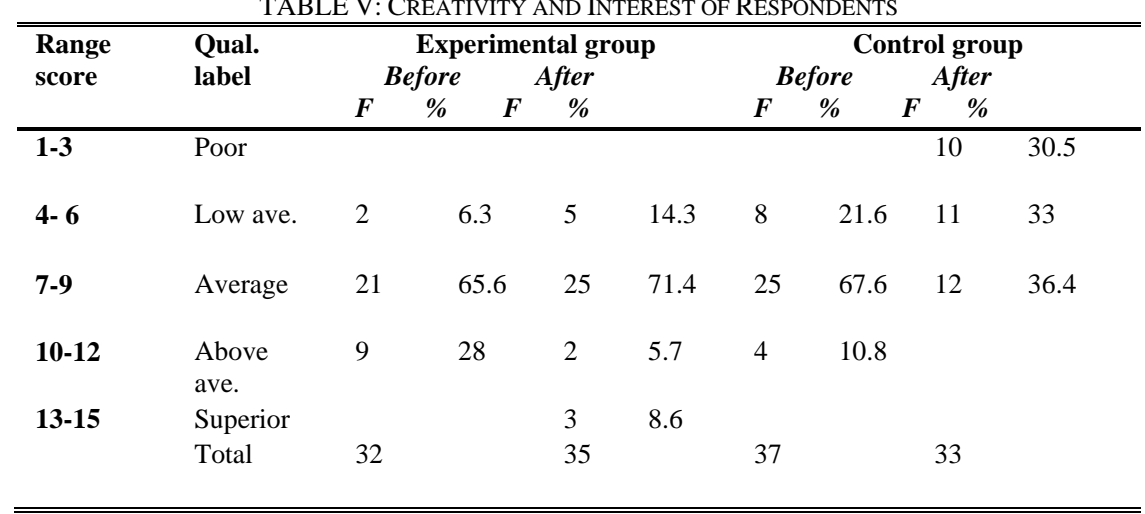

\section{F. Self Assessment}

Self assessment evaluates the quality and contributions of HOTS through modular instructions to the students learning and knowledge gained after the treatment. (See Table VI)

TABLE VI: SUMMARY OF SELF-ASSESSMENT ON THE USE OF MODULAR INSTRUCTIONS USING HOTS TECHNIQUES

\begin{tabular}{|c|c|c|c|}
\hline "Assessment Questions & Response & $\bar{F}$ & $\%$ \\
\hline $\begin{array}{l}\text { How would you rate the } \\
\text { modules? }\end{array}$ & Above average & 12 & 32.4 \\
\hline $\begin{array}{l}\text { Do the activities in the modules } \\
\text { arouse your interest? }\end{array}$ & Yes & 30 & 81.0 \\
\hline $\begin{array}{l}\text { Do the modules improve your } \\
\text { creativity and interest in } \\
\text { chemistry? }\end{array}$ & Yes & 33 & 89.2 \\
\hline $\begin{array}{l}\text { What is/are the most interesting } \\
\text { activity? }\end{array}$ & $\begin{array}{l}\text { Balancing } \\
\text { equation }\end{array}$ & 15 & 40.5 \\
\hline $\begin{array}{l}\text { What activity enhances your } \\
\text { creativeness the most? }\end{array}$ & Concept mapping & 9 & 24.3 \\
\hline $\begin{array}{l}\text { What activity enhances your } \\
\text { thinking the most? }\end{array}$ & $\begin{array}{l}\text { Limiting reagent } \\
\text { analysis }\end{array}$ & 10 & 27.0 \\
\hline $\begin{array}{l}\text { Do the content and activities } \\
\text { enhance your learning style? }\end{array}$ & Yes & 20 & 54.0 \\
\hline $\begin{array}{l}\text { Do HOTS techniques used } \\
\text { encourage and motivate you to } \\
\text { study and learn chemistry? }\end{array}$ & Yes & 17 & 32.4 \\
\hline $\begin{array}{l}\text { What are your comments \& } \\
\text { suggestions? }\end{array}$ & None & 22 & 59.5 \\
\hline Some comments & $\begin{array}{l}\text { Hard, perfect, } \\
\text { repeat }\end{array}$ & 15 & 40.5 \\
\hline
\end{tabular}

\section{DISCUSSION AND IMPLICATIONS}

On the basis of pre-test and post-test profiles using HOTS questions, the respondents in both groups performed better during post-test, compared to their pre-test performance. This may be due to the discussion of concepts that are related equally to the concepts covered by the HOTS questions. However, experimental group performed better in the post-test than their counterparts. This implies that the modular instructions using HOTS techniques improve their achievement in chemistry. On the other hand, the poor performance of the respondents on HOTS questions demands serious attention. One may have to take a look at the prerequisite stock knowledge and skills learned by the students. A more critical examination must be done in order to determine if there is a need to re-teach the concept. An important implication is that the respondents are not used or properly trained to answering HOTS questions. Worth noting is the fact that although there is some discernible improvement in the performance of the experimental group participants compared to the control group, however, some participants in the experimental group performance is still poor after treatment,. The small changes in respondents' performance after treatment may be attributed to some factors beyond the control by the researcher. These include limited time and contact due to the Ramadhan season, tardiness of the students, and their observed laziness or lethargy in class. Per observation of the researcher, students attended classes irregularly during Ramadhan, and looked so tired and weak. Furthermore, the students have poor vocabulary knowledge and cannot understand some terms used in the questions. 
The significant increase of the means during post-test in both groups implies that the respondents tried to answer the questions that called for higher order thinking skills. The higher significant value in the experimental group compared to the control group indicates that the group tried to apply their knowledge gained from the HOTS techniques to which they had been exposed. Furthermore, their thinking skills maybe more developed and improved compared to those of the control group who does not undergo any treatment at all. The respondents in the experimental group said that "not all the lessons we have is easy, sometimes is difficult". The significant difference in the mean gains between the groups indicates that the experimental group who used the HOTS techniques performed better on the HOTS questions compared to the control group. This implies that the HOTS techniques used by the researcher had a positive effect on the development of the critical thinking skills of the respondents. H. Ali, N. (respondent) says that "I believe that these modules can help me to give more ideas advance in college. I feel happy in all activities; it is more challenging, more enjoyable and very hard like solving problems".

The positive overall assessment of the respondents (experimental group) of the HOTS techniques and activities presented in the modules implies that the students want change in the teaching methods and are ready and eager for techniques that activate the learning process. It implies further that more challenging roles will help develop their critical thinking skills and that critical thinking is very important because it enables one to analyze, evaluate, and restructure his/her thinking. It does not involve simply acquisition and retention of information or the possession of a skill-set which one does not use regularly. Many of the respondent said, "I know that modules in chemistry can help me when I go to college". "When time of activities, I feel so happy but when I have no answer I'm so sad".

\section{REFERENCES}

[1] TIMSS - R, "Philippine Report Volume 1," Science Department of Education Culture and Sports: DOST, Science Education Institute and UP National Institute for Science and Mathematics Education Development, 2000.

[2] A. Valdez, "Language of the TIMSS-like test and student's performance in general science," Thesis, Mindanao State University, Philippines, 2002.

[3] M. A. Darmer, "Developing transfer and metacognition in educationally disadvantage students: effects of the HOTS program," University of Arizona, 1995.

[4] What's Your Learning Style. (2007). [Online]. Available: http://www.usd.edu/trio/tut/ts/stylest.html.

[5] Dissertation Abstract International, vol. 55, 1995.

[6] K. Buttler, "Learning Style, personal exploration and practical applications: An introduction to style for secondary students," Columbia, CT. The learners dimension, 1995.

[7] M. L. Corner, "What's Your Motivation Style," 1993-2007.

[8] E. Von Glaserfeld. (1989). Cognition, construction of knowledge and teaching. [Online]. Available: http://www.org.edu.von.com.

[9] S. Caster, "The influence of training method, factors for cognitive ability, motivation and affect on training outcomes," Dissertation Abstract International VM55, no. 8, 1994.
[10] C. E. Schaefer, "Creativity Attitude Survey," Jacksonville, IL, Psychology and Educators Inc, 2007.

[11] J. W. McMahon, F. B. McMahon, and T. Romano, Psychology and you, $2^{\text {nd }}$ ed., 610 Opperman drive St. Paul, MV 55164-0526 West Publishing Company, 1995.

[12] S. Chen, B. Mulgrew, and P. M. Grant, "A clustering technique for digital communications channel equalization using radial basis function networks," IEEE Trans. on Neural Networks, vol. 4, pp. 570578, July 1993.

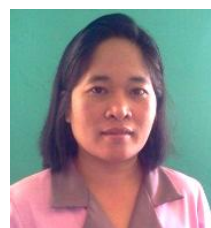

Anabelie V. Valdez was born at Aurora Zamboanga del Sur Philippines on March 16, 1975. She finished $\mathrm{PhD}$. Science education biology, $\mathrm{PhD}$ educational management, Master's in secondary teaching general science and Bachelor of Science secondary education biology in Mindanao State University Marawi City Philippines. She is a college and high school faculty in the said university and the main author/researcher of this research. Research interest is in science education and indigenous knowledge.

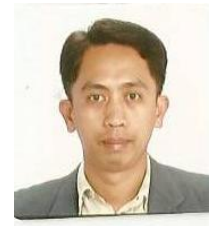

Solaiman B. Mangorsi was born in Marawi City, Philippines. He finished Ph.D. in Science Education Mathematics, Master of Science in Teaching Mathematics and Bachelor of Science in Mathematics in Mindanao State University Marawi City. A mathematics faculty of the Mindanao State University Marawi City since 1999, co - authored the Preparatory College Mathematics and Pre-University Center Mathematics Workbook at the Mindanao State University in Marawi City. Research interest is in math education

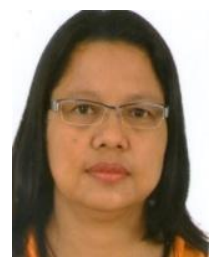

Vilma D. Hambre was born at Dumingag, Zamboanga del Sur, Philippines on March 06, 1968. He finished $\mathrm{PhD}$ Science Education Mathematics at Mindanao State University MarawiCity, Philippines. Master of Arts in Teaching High School Mathematics and Bachelor of Secondary Education Major in Mathematics at Mindanao State University Iligan Institute of Technology, Tibanga, Iligan City, Philippines. She is a math faculty member of Marcela T. Mabanta National High School of the Department of Education in the Division of Lanao del Norte, Tubod, Lanao del Norte, Philippines. Research interest is in math education and innovations.

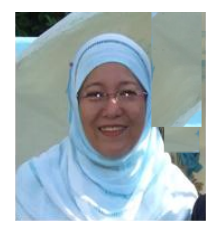

Maryam Q. Manalundong is a civil engineer and a professional mathematics teacher, born in Manila on January 5, 1964. She finished her Bachelor of Science in Civil Engineering in Adamson University, Ermita, Manila; Diploma in Teaching High Schoo Mathematics and Master of Science Education in Secondary Mathematics (CAR) at Mindanao State University-Institute of Science Education; and Magnacarta in Education in Jamiatul Muslim Mindanao, Marawi City. She is presently connected at MSU-Balindong Community High School, Balindong, Lanao del Sur as Mathematics Teacher, IT Coordinator/encoder, and Quizzers Club Team Coach/Adviser.

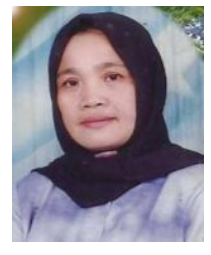

Dayamun T. Magdara is a native in Marawi Lanao del Sur. She finished $\mathrm{PhD}$ in science education Biology, MST in General Science at Mindanao State University. She finished BSeD Biology at Mindanao State University -Iligan Institute of Technology Iligan City. She is a permanent faculty in Mindanao State University Marawi City Philippines. Research interest is in science education. 